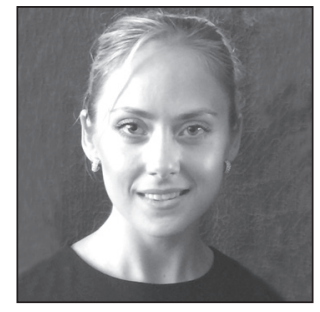

Liisa Abel

Doctoral student, University of Tartu

Adviser to the Public Order and Criminal Policy Department

Ministry of the Interior

\title{
A Legal Cultural Model as a Theoretical Basis of Reintegration Strategies for ISIS Ex-militants
}

\section{Introduction}

The rising threat of violent extremism in recent years has become widely discussed by mass media. Topics associated with how to combat violent extremism or how to counter radicalisation appear in the media so frequently that they are becoming part of public discourse.

When we talk about violent extremism, we firstly have to talk about Daesh ${ }^{{ }^{*}}$, also known as ISIS ${ }^{{ }_{2}}$ or ISIL $^{*}$. This organisation is known for being a brutal, deadly, and extremely vitality-rich terrorist movement that has more territorial, material, and human resources than any other the world has ever seen. ${ }^{*}$ It has also been called the greatest threat to world peace, not to mention that its fanaticism and disciplined organisation are now being compared to those of the Nazi regime. ${ }^{*} 5$ Making matters worse is that more than 80 countries have had to face the fact of their citizens having joined ISIS $^{* 6}$ and now being considered ISIS militants ${ }^{*}$.

It is also known that approximately 60 per cent of the people who have joined ISIS to act as militants are going to be killed during the battles or via suicide; 20 per cent of the people who have joined ISIS will flee to places other than their home country, such as Yemen or the Philippines, never to return home; and about 20 per cent of the militants will return home of their own volition or be administratively sent back to their home countries ${ }^{*}$. Once they are back in their home countries, there is good reason to believe that the

\footnotetext{
An Arabic acronym used as a pejorative for ISIS.

Islamic State of Iraq and Syria.

Islamic State of Iraq and the Levant.

4 A. Lekas. \#ISIS: The largest threat to world peace trending now. - Emory International Law Review 30 (2015) / 2, pp. 314-315.

$5 \quad$ Ibid., p. 314.

6 In September 2014, CIA reports estimated that ISIS had recruited 31,500 people to fight in Iraq and Syria, from 81 distinct countries. Information is available at http://edition.cnn.com/2014/09/11/world/meast/isis-syria-iraq/ (most recently accessed on 15.12.2016).

7 Also known as ISIS fighters, combatants, or warriors.

8 Information from a confidential source provided by employer the Ministry of the Interior of the Republic of Estonia.
} 
intelligence agencies will find them and that in some cases they will be prosecuted and convicted on charges of terrorism. Accordingly, the former terrorists will have to stay in prison for years. However, they may not stay in prison for life. ${ }^{* 9}$

Scholarly discussion is more than adequate about questions that concern releasing imprisoned terrorists back into the society. Can prison help them to turn away from terrorism? Do they have a place to go, and, furthermore, who will monitor them? And then there is the most important question - will they re-offend? ${ }^{* 10}$ The main goal for this article is to analyse whether the prison system in Estonia, after incarcerating former ISIS terrorists, would be able to fulfil the objectives set for the execution of the imprisonment. In the context of the article, the latter refers to helping the inmate lead a law-abiding life and defend public order $^{* 11}$, with the (legal) cultural aspects of the different societies taken into account. The article will also briefly discuss the issues related to releasing imprisoned terrorists into the surrounding society.

The main concern addressed by the article is that there might not be potential to re-socialise an individual who does not feel part of the society in which he is incarcerated (and may not even want to be a member of it unless the integration process takes into account not only the aspects of (legal) culture that are familiar and well-known in the society where the person is incarcerated but also the ones that the prisoner considers to be essential.

\section{From radicalisation to de-radicalisation}

When we talk about an average prisoner in Estonia, it can be stated that the applicable characterisation of an inmate largely depends on the offence committed. There is no universal, all-embracing characterisation. White-collar crimes tend to be committed by wealthy people, usually with a good education ${ }^{{ }^{*}{ }^{12}}$; there are 'smaller' offences, in the case of which a lack of education is common (e.g., offences against property); and there are very serious ones in connection with which we can sometimes talk about a specific medical condition (e.g., paedophilia-linked crimes). ${ }^{*}{ }^{13}$ All those individual prisoners need a specific approach, with dissimilar 'tools' - some of them need an education, some therapy-based treatment, while others might need to acquire a profession while being in prison if they are to live a law-abiding life outside prison.

The state has an obligation toward people who have committed crimes and are now being incarcerated and also one towards the society as a whole to help those people. This means that the state has to defend public order and help prisoners in such a way that these people could in the future live a law-abiding life. But when we talk about a law-abiding life, we are actually speaking of reintegration: helping the prisoner to understand the social obligations and rules surrounding him so that it is feasible to rule out the possibility of him spending his entire life in prison. That is the reason that, when a person is in prison, his criminality risks and needs are surveyed, for understanding what would help him such that in the future he will not commit criminal acts. ${ }^{*} 14$

One topic of heated debate is the reintegration of former terrorists, who are also described as returned or former violent extremists and as people who are radicalised. ${ }^{* 15}$ In the context of this article, a radical individual is defined as a 'person harboring a deep-felt desire for fundamental sociopolitical changes' and radicalisation is understood as 'a growing readiness to pursue and support far-reaching changes in society that conflict with, or pose a direct threat to, the existing order. ${ }^{*}{ }^{16}$

9 For example, the Estonian Penal Code provides that even if a person has been sentenced to life imprisonment, the court may release that person on parole if the offender has actually served at least 30 years of the term of punishment imposed. Penal Code (karistusseadustik). - RT I 2001, 61, 364 (in Estonian).

10 J. Horgan, K. Braddock. Rehabilitating the terrorists? Challenges in assessing the effectiveness of de-radicalization programs. - Terrorism and Political Violence 22 (2010), p. 268. - DOI: https://doi.org/10.1080/09546551003594748

11 Imprisonment Act (vangistusseadus). - RT I 2000, 58, 376 (in Estonian).

12 E.S. Podgor. The challenge of white collar sentencing. - Journal of Criminal Law \& Criminology 97 (2007) / 3, p. 740.

13 S. Feelgood, J. Hoyer. Child molester or paedophile? Sociolegal versus psychopathological classification of sexual offenders against children. - Journal of Sexual Aggression 14 (2008) / 1, p. 34. - DOI: https://doi.org/10.1080/13552600802133860.

14 Kriminaalhoolduse standardid ['Standards of probation'], 2014, pp. 21, 30. Available at http://www.vangla.ee/en (most recently accessed on 1.1.2017) (in Estonian).

15 M. Chin et al. A national strategic framework for countering violent extremism in Jordan. - Journal of International Affairs 69 (2016) / 2, p. 125.

16 A. Dalgaard-Nielsen. Violent radicalization in Europe: What we know and what we do not know. - Studies in Conflict \& Terrorism 33 (2010) / 9, p. 798. - DOI: https://doi.org/10.1080/1057610x.2010.501423. 
Reintegration of a former terrorist demands numerous kinds of interventions that must occur after the individual has already been radicalised. Such interventions usually consist of three steps: disengagement, de-radicalisation, and finally the reintegration. ${ }^{*} 17$ The primary concern is how to prevent a person from returning to violent extremism.

Through disengagement, it is possible to achieve change in the person's behaviour (i.e., refraining from violence and withdrawing from a radical organisation) but not necessarily a change in beliefs. Deradicalisation as a central element in the process is understood as a change at the cognitive level - a social and psychological shift whereby the person's commitment to, and involvement in, violent radicalisation is reduced to the extent of no longer being at risk of re-engaging in terrorist activity. ${ }^{*} 8$ This theory is based on the premise that, just as there are processes through which an individual becomes an extremist, there are also processes through which an extremist can come to relinquish violence or even in some cases discard a radical ideology. ${ }^{* 19}$ Scholarly discussions about de-radicalisation imply a possibility of lasting change in orientation. ${ }^{* 20}$ After conclusion of the first two steps, it is possible to actually reintegrate the former terrorist, as has been done with 'regular' prisoners.

\section{Potential reintegration problems with the ex-militant}

In many parts of the world, specific programmes are in place that use a combination of psychiatry, education, and religion to deal with former terrorists. But these programmes are successful only if they are grounded in a clear understanding of what motivates people to join terrorist movements and what motivates them to leave. ${ }^{* 1}$ Therefore, it is crucial both to understand the ideology that urges terrorists to commit terrorist acts and to meet the sociological needs these persons might have (e.g., that of belonging or for a collective identity). ${ }^{* 2}$

In Estonia, there have not yet been any former violent extremists who need to be reintegrated, although there are people who have left the country to join ISIS to fight in the jihad. Were those militants to be prosecuted and convicted on terrorism charges here in Estonia, they would have to stay in prison for years.

With every prisoner whose confinement lasts more than one year, the reintegration process starts as soon as possible. ${ }^{* 2}$ In the event of the Estonian prison system being required to reintegrate a former violent extremist, those involved must know the answers to many, quite different questions that may arise while they are carrying out the work: What is the (legal) cultural background to which the person belongs nowadays? What are the values this person carries with him? And what are his views about the society into which he is going to be integrated?

One of the most complex questions is this: what if he does not want to be part of the culture within which he is serving his sentence? Into which society are we integrating this person then? For understanding what helps to reintegrate former terrorists and withdraw them from violent extremism, there is a need to grasp what (legal) cultural factors might have influenced their radical ideology. To explore this, below, the author will use the specific legal cultural model provided by Professor Jørn Øyrehagen Sunde for ascertaining those bearings.

17 M. Chin et al. (see Note 15), p. 116.

18 Ibid., p. 124.

19 E.M. Markisen. Juvenile law and jihad: Exploring anti-terror legislation and calling for mandatory juvenile treatment of radicalized teens joining ISIS in Syria. - Wisconsin International Law Journal 34 (2016) / 1, p. 205.

20 J. Horgan, K. Braddock (see Note 10), p. 280.

21 E.M. Markisen (see Note 19), p. 205.

22 Ibid., pp. 205-206.

23 The Imprisonment Act (\$16) specifies that a prisoner whose actual term of imprisonment exceeds one year shall receive an individualised treatment plan, which prescribes, for example, the prisoner's ability to work and professional skills, while also specifying any need to provide general education, vocational education, or in-service training for the purpose of professional development to the prisoner; the privileges to be granted to the prisoner; etc. 


\section{The legal cultural model}

Prof. Sunde has described legal culture as a social phenomenon that changes with the society and its needs. Also, that legal culture is something that is inherent to a certain social community, and internalisation of it is what has given the law its legal cultural dimension. ${ }^{{ }^{2} 4}$

Integrating a prisoner who subscribes to a radical ideology rooted in the major world religion Islam ${ }^{* 25}$ into Estonian society entails an integration interface between two, quite different cultures. On one hand, the individual is in a secular country and is required to obey the rules established there, but at the same time his inner convictions stem from the Islamic tradition. So there is a need to get to know both (legal) cultures.

The model consider here is divided into two parts, which are in symbiosis with each other. The first part, denoted as 'institutional structure', refers to institutions that establish rules and settle disputes. The other part of the model is named 'intellectual structure', and it represents the ideas and expectations that shape the law. ${ }^{* 26}$

The model contains six elements that must be examined if it is going to yield understanding of a specific legal culture. When one finds meaning for these elements, it then is possible to understand what the legal culture looks like or even how it functions. Those six elements are conflict resolution (a society's most basic demand of its legal system); norm production (from case law to codification of law); the concept of justice (with justice being a fundamental demand made of the law); legal method (for resolving a specific case in accordance with the concept of justice); professionalisation of law (meaning that there are special criteria to fulfil before one can be trusted with the position of handling law) and the influence of internationalisation (addressing the idea that as society changes, the law must change such that it remains able to fulfil its obligations in conflict resolution amid that change). ${ }^{{ }_{2} 7}$

In the case considered here, three of the elements described above must be considered via comparison of parameters from different legal cultures, for understanding of why reintegration of a former ISIS militant might not be successful. These are conflict resolution, the idea of justice, and the influence of internationalisation.

Before we explore these elements, it has to be remarked that this model can truly help us to characterise different legal cultures but not deviations. It would be irresponsible to attempt to analyse the legal cultural background of ISIS (activity). Therefore, the purpose for using this model here is to characterise only the similarities and differences between specific (legal) cultures and then explain how this knowledge can be employed for a favourable effect in integration of a former terrorist.

\subsection{Law and its values - the idea of justice}

Harold J. Berman believes that there are some characteristics of law that tend to give it a 'sacred' quality for people, meaning that these support basic emotions in relation to the law that also have a religious component - feelings of responsibility and obligation, a sense of satisfaction and gratitude when justice is done. ${ }^{*} 28$ He believes that law everywhere communicates its values:

(a) through ritual, that is, formal procedures of legislation, adjudication, and administrative regulation that symbolize its objectivity,

(b) through tradition, that is, distinctive legal language and practices handed down over generations and centuries that symbolize its continuity with the past and its ongoingness into the future,

(c) through authority, that is, reliance upon written or spoken sources that effectively symbolize its binding power, and

24 J.Ø. Sunde. Champagne at the funeral - an introduction to legal culture. - J.Ø. Sunde, K.E. Skodvin (eds), Rendezvous of European Legal Cultures, pp. 11-28. Bergen 2010, p. 15.

25 E.M. Markisen (see Note 19), p. 206.

26 J.Ø. Sunde (see Note 24), pp. 22-23.

27 Ibid., p. 28.

28 H.J. Berman. Comparative law and religion. - Mathias Reimann, Reinhard Zimmermann (eds), The Oxford Handbook of Comparative Law. 2012, p. 746. 
(d) through universality, that is, justification of itself in axiomatic terms as the embodiment of universally valid principles and concepts - that contracts should be kept, that wrongful injuries should be compensated, that crimes should be punished, that property rights should be protected, that one accused of an offence is entitled to a hearing, and the like. ${ }^{* 29}$

In relation to the notion that the state (through the law) is the one that must deliver justice and verify it among society through ritual, tradition, universality, and authority, it can be said that in Estonia, a country belonging to the West, people usually see justice as a moral concept mixed with political means, with justice as the "most fundamental of all virtues for ordering interpersonal relations and establishing and maintaining a stable political society'. ${ }^{*} 30$ In Estonia and generally in the West, there is a respect for human dignity and cultural diversity.

Countries belonging to the Islamic (legal) culture (often loosely referred to as the Middle East), despite distinguishing between secular law and God's law, see the state as a high ideal for suppressing all injustice and exploitation and for encouraging a society guided by purity, goodness, and virtue for people's prosperity. ${ }^{*}{ }^{11}$ So it can be said that the Islamic system thereby has its roots in the idea of welfare of mankind, in any age and at any time under any political order. ${ }^{*} 32$

Hence, irrespective of whether God's law or man's is at issue, the main value and main purpose of the law is to provide for the well-being of mankind both in the West and in the Middle East.

What is the idea of justice held by ISIS militants? There is no scientific literature about their specific idea of justice. However, it can be stated that ISIS militants believe that Muslims should return to the simplicity and unity of early Islam - this is something that God wants from people. ${ }^{*} 33$ They believe they can achieve that through establishing a community of believers who practise Islam in its purest form, even though that means waging war against the infidels. Justification of their acts is found in the goal of restoring a caliphate in line with the earlier Muslim golden age in accordance with God's wishes. ${ }^{*} 34$

So ISIS militants commit violence in the name of Islam but not violence permitted by Islam - 'acts of violence, whether against Muslims or non-Muslims, such as: indiscriminate killings, beheadings, rapes, slavery, destruction of public and private property, pillage, and theft, violate the sharia and Islamic law'." ${ }^{35}$ The foregoing means that they do not underpin their actions with caring about the welfare of mankind or try to advance social justice and dignity for all as Islamic tradition expects and as also is the primary aim for God's law in Islamic tradition.

\subsection{Conflict resolution}

In the West, conflict resolution is understood as a process based on valid law provided by the legislator that involves legal disputes and settling of those disputes in a manner that helps to achieve peaceful ending of the conflict, with acknowledgement of the legitimacy of differences in beliefs and interests between the disagreeing parties. The main process of conflict resolution in the West consists of conciliation facilitation, mediation, negotiation, arbitration, and problem-solving. ${ }^{*}{ }^{6}$ The most important element is that the settlement of the conflict is secular.

The Middle East is home to diversity of societies, including several languages, histories, races, and cultures, with each having certain fundamental conflict-resolution principles and practices. ${ }^{*}{ }^{37}$ Conflict

99 Ibid., p. 746.

30 Western theories of justice. Available at http://www.iep.utm.edu/justwest/ (most recently accessed on 22.12.2016).

31 A. Ilyas. Relevance of [the] Islamic system of governance in the age of globalization. - Dialogue (1819-6462) 11 (2016) / 2, pp. 189-201, on p. 189.

32 Ibid., p. 189.

33 R. Barrett. The Islamic State. New York: The Soufan Group 2014, p. 9.

34 P. Layton. Bringing the transnational into "new wars': The case of Islamic State. - International Review of Social Research 5 (2015) / 3, p. 193.

35 M.C. Bassiouni. Misunderstanding Islam on the use of violence. - Houston Journal of International Law 37 (2015) / 3, p. 651.

36 L. Nussbaum. Mediation as regulation: Expanding state governance over private disputes. - Utah Law Review 361 (2016) / 2, p. 367.

37 M. Abu-Nimer. Conflict resolution in an Islamic context. - Peace \& Change 21 (1996) / 1, p. 32. - DOI: https://doi. org/10.1111/j.1468-0130.1996.tb00253.x. 
resolution in the Middle East, in Islamic context, knows at least two domains: the historical-religious domain and the domain that actually embraces the Islamic society itself. For the first of these, we talk about the Quran, which is the most comprehensive holy-religious source of guidance sharia, or Islamic law ${ }^{*} 38$; the Sunnah, as the Prophet's proclamations (also known as Hadith); and the accounts of caliphates. In the second, there are conflict-resolution processes on interpersonal and community levels (mediation, arbitration, etc.) that involve various individuals and groups (husbands, clans, etc.) and also the processes that involve policymaking and political groups' interactions. ${ }^{*} 9$

Hence, there are obviously major differences in conflict resolution between the West and the Middle East. In the West, a conflict is considered positive and normal, as able to bring with it growth and creativity. In the Middle East, a conflict is deemed negative and dangerous, so it should be avoided; it brings destruction and disorder. Social norms and values rather than legal forms are the main rules of commitment. ${ }^{*} 40$

Whatever the differences from one society to the next, a just resolution to a conflict is the one where an individual truly apprehends what he did wrong and what the circumstances of his acts might be. We could add that if people do not share a common faith in the law as a process of just resolution of conflicts, they might feel undermined and harmed by the outcome of the conflict resolution. Clearly, that might be the case where a former terrorist is concerned.

As was noted above, a terrorist by committing his unlawful acts expresses a belief that he is performing a religious obligation towards God. ${ }^{* 1}$ So in terrorists' eyes, by fulfilling the ultimate obligation they might end up incarcerated for life. Furthermore, the person considered need not be a former terrorist for the cultural dimension of differences in apprehending what is a just resolution of conflict to be evident.

For example, when a person gets killed in an Islamic country, the state will not start an investigation unless the relatives of the dead person demand it. That is because killing is an act against the citizen, not the state. At the same time, acts against God in Islamic countries are so serious that there will always be an investigation - one example being acts of homosexuality, which in the West are not crimes but a normal part of society. In contrast, killing a person is considered to be a very serious crime in the West. ${ }^{* 2}$ Therefore, people from an Islamic tradition might find the conflict resolution in the West inequitable because it does not differentiate God's laws from secular ones. In addition, the conflict resolution itself is not based on the laws of God, which from their perspective would be clearly prioritised in comparison to laws that are written by men rather than provided by God in conflict resolution.

The prevailing belief, at least in the Western tradition, is that the punishment has to be effective and at the same time proportionate to the crime. ${ }^{*} 43$ Can a punishment that does not feel or seem fair to its subject be effective? Or is only a bigger confrontation going to result? Maybe there are some techniques and concepts in Western conflict-resolution models that can never be applied in Islamic societies, or at least there is no basis for implementing or applying Western strategies in Islamic context without adjusting and redefining said processes in accordance with local experience. ${ }^{*} 44$

There are authors who go even further, saying that in Islamic societies there has been and continues to be from one generation to another, especially among fundamentalist groups, a feeling of humiliation and antagonism toward the West and that such an atmosphere constitutes a major obstacle to the application or even consideration of Western conflict-resolution principles. ${ }^{*} 4$

38 Some authors claim that sharica and Islamic law are distinct from one another, with the latter being complementary to the sharica, which is the primary source. One such author is M.C. Bassiouni (see Note 35).

39 M. Abu-Nimer (see Note 37), pp. 35-36.

40 Ibid., p. 31.

41 E.M. Markisen (see Note 19), p. 206.

42 J.Saar. Kuritegevus muutuvas maailmas. Kultuurilis-tsivilisatsiooniline lähenemine ['Crime in a changing world: A culturalcivilisation approach']. - Akadeemia 2011/9, pp. 16, 23.

43 R. Paternoster. How much do we really know about criminal deterrence? - Journal of Criminal Law \& Criminology 100 (2010) / 3, p. 769.

44 M. Abu-Nimer (see Note 37), p. 27.

45 Ibid., p. 33. 


\subsection{Internationalisation}

In Islam, the law is controlled by theology ${ }^{*} 46$, based on the Quran and its interpretation in the form of sharia*47. The purpose of Islamic law as a practically framed legal system has been 'the creation of a unity on moral and spiritual grounds' among people of different cultures and ethnicities. ${ }^{*} 48$ In the West, the law is created and controlled by men, not by God. However, differences in tradition in law are not the only reason for the internationalisation process between these two (legal) cultures being complicated.

Samuel Huntington has said that there exists a fundamental conflict between democracy as rules in the West and the ideology of Islamism. ${ }^{*} 49$ There are authors who state that this claim is overstated and that we should see the relationship between Islam and democracy as, rather, a complex one. ${ }^{*} 50$ There is a competing view to the latter according to which we can already talk about 'civilizational despair', about an inevitable clash of civilisations. Its adherents espouse the idea that confrontation between Islam and the West is escalating because of people who are using Islam as a justification to their ideologically motivated violence ${ }^{*} 51$, labelling the others as 'infidels' or Muslim secularists who are misled and need to be corrected while considering themselves the owners of the ultimate truth. ${ }^{*} 52{ }^{*} 53$

So in light of globalisation, especially when we talk about cross-border crimes, crime control needs to take into account that there are not only countries but also civilisations that in some places are slowly starting to rule over the countries ${ }^{*} 54$ or run their criminal-justice systems.

Professor Sunde has stated that internationalisation is closely connected to conflict resolution, meaning that law must change as society changes. Only then can it fulfil its obligation in conflict resolution. ${ }^{*} 55$ The problem is that our societies are indeed changing but doing so more rapidly than the law can or than people want it to change. That is because each cultural space holds its own values - Western countries are especially afraid of potential loss of legitimacy of the rule of law, which is a huge part of Western countries' identity and which loss is irreparable. At the same time, the law has to be efficient in all respects, for all people living within the jurisdiction of the country in question, which means that there is a need to take into account the civilisational-cultural factors that indirectly affect lawmaking.

The main reprimand against the West is that, because Islam has not been part of its cultural tradition, the West 'fails to take into account Muslim societies' cultural diversity and their respective human, social, and economic conditions'. ${ }^{*}{ }^{6}$ Furthermore, it has been said that, in a phenomenon that is under-reported, Muslims are actually the ones who have suffered great losses, because of wrongful and violent practices or the misleading religious beliefs held by some other Muslims who are taught by unqualified self-appointed imams. What is in the foreground and what has been emphasised is the victimisation of Westerners. ${ }^{*} 7$

There is an urgent need to fight against terrorism, but the main lesson to be learnt in connection with internationalisation in Islamic versus the Western context may be that we need to recognise that declaring a war on jihad is not the solution. This rather contributes to fighting against consequences. For successfully

46 M.C. Bassiouni (see Note 35), p. 665.

47 A. Ilyas (see Note 31), p. 195.

48 Ibid., p. 195.

49 S.P. Huntington. The Clash of Civilizations and the Remaking of World Order. New York 1997, pp. 183-254.

50 G. Crowder et al. Islam, Islamism, and Post-Islamism: Rediscovering politics after the War on Terror. - Australian Journal of Politics \& History 60 (2014) / 1, p. 111. - DOI: https://doi.org/10.1111/ajph.12048.

51 M.C. Bassiouni (see Note 35), p. 675.

52 M. Abu-Nimer (see Note 37), p. 33.

53 'Many fundamentalist groups believe that there is one correct understanding of the straight path of Islam; ipso facto, all others are deviations and will not receive divine reward,' according to one account. Q. Wiktorowicz, K. Kaltenthaler. The rationality of radical Islam. - Political Science Quarterly (Wiley-Blackwell) 131 (2016) / 2, p. 440. - DOI: https://doi.org/10.1002/ polq.12480.

54 Some sources claim that the police in Sweden continue to lose control of more and more suburbs in major Swedish cities, for they have now admitted that there are more than 55 'no-go areas' where they have major problems enforcing the law. Hungary's government has claimed that there are 900 'no-go zones' in London, Paris, Stockholm, and Berlin. The problem is that migrants want to live under their own rules outside the society of Sweden, London, Paris, etc. Citations are available, for example, at http://www.bbc.com/news/magazin-e37578919 and https://www.theguardian.com/world/2016/mar/31/ hungary-anti-migrant-site-900-no-go-areas-eu (most recently accessed on 1.1.2017).

55 J. Ø. Sunde (see Note 24), p. 24.

56 M.C. Bassiouni (see Note 35), p. 645.

57 Ibid., p. 646. 
facing the internationalisation security challenge entailed by the interface between different cultures, we must deal with the young Muslims who might not see any way 'out of the cycle of violence, corruption, and poverty. Coupled with the condition[s] of unemployment and marginalisation, contempt and sarcasm, exploitation and scorn that many suffer'. ${ }^{5} 8$

At the same time, there is, of course, an additional view on the internationalisation problem. That involves the idea that today, in all parts of the world, in all their variety, Christian-Muslim interaction is a reality. Although several people have been on record as praising the commonality of these traditions, influential and significant differences remain. ${ }^{59}$

\subsection{Conclusions based on the model}

The author chose the lens of the legal cultural model for purposes of characterising the similarities and differences between the two major (legal) cultures at issue. The question was this: how can it contribute to knowledge and a positive outcome when one is integrating a former terrorist?

The model, firstly, aids in revealing some of the main differences and similarities between the two (legal) cultures - the Western and the Islamic - such that one can then describe what aspects both (legal) cultures signify and what the core of their values/beliefs is. The most important thing to comprehend is that former terrorists, even when apparently integrated into secular Western society, retain an affiliation that lies mostly with the Islamic tradition.

The fundamental condition for integration of an ex-militant is to understand that terrorists' idea of justice and their justifications for their acts are based on their misinterpretation of the Quran and God's will. That is something that can be clearly seen from the model's interpretation. In many cases, terrorists are not properly educated in the religion they think themselves to represent ${ }^{*} 60$. That is also why de-radicalisation programmes used by several of the world's prisons have been built in line with a conviction that most terrorists do not have a proper understanding of the ancient Islamic religion and that this has made them highly vulnerable to extremist propaganda and 'teachings' of self-appointed imams. That is the substantial reason they can be re-educated and reformed. ${ }^{*} 61$

Although there has been a large amount of debate surrounding how to evaluate the de-radicalisation programmes and their outcomes, some experts have expressed a belief that reintegration of former terrorists has been successful. ${ }^{* 62}$ So if there is a question of whether it is possible at all to release a terrorist back into society without the risk of him committing new crimes, we can answer that yes, it should be possible. ${ }^{* 6}$

Also, this should not be a problem in Estonia, at least in theory, since this is a country that respects human rights and guarantees prisoners their freedom of religion as the Constitution of Estonia demands ${ }^{* 64}$ while at the same time providing knowledge, with the assistance of a chaplain and experts, about the true nature of Islam. The former terrorists will also be given skills and knowledge of how to live a law-abiding life. For example, reintegration in prison includes working with a detainee's personal, economic, and legal issues to help the prisoner maintain and create important and positive social contacts outside prison and to increase his ability to act in accordance with the law. ${ }^{*} 6$ But there is still a potential stumbling block.

The programmes themselves are very expensive, and the success of these costly programmes depends largely on the 'after-care' measures the state can use. Those follow-up measures can involve monitoring

58 S. Benhabib. Piety or rage? On the Charlie Hebdo massacres, p. 2. Formerly available at http://www.hannaharendtcenter. org/wp-content/uploads/2015/01/Piety-or-Rage.pdf (10.12.2016). --or-- Available at http://69.89.27.220/ hannaha2/ wp-content/uploads/2015/01/Piety-or-Rage.pdf (most recently accessed on 21.9.2017).

59 See P.L. Heck's comment on his book Common Ground: Islam, Christianity, and Religious Pluralism. Available at http:// press.georgetown.edu/book/georgetown/common-ground (most recently accessed on 10.12.2016).

60 M. Hasan. How Islamic is Islamic State? New Statesman, 10 March 2015, pp. 11-13. Available at http://www.newstatesman.com/world-affairs/2015/03/mehdi-hasan-how-islamic-islamic-state (most recently accessed on 16.12.2016).

61 E.M. Markisen (see Note 19), p. 205.

62 See M. Levitt et al.'s article 'Rehabilitation and reintegration of returning foreign terrorist fighters', published by the Washington Institute for Near East Policy on 23 February 2015, p. 4. Available at http://www.washingtoninstitute.org/policy-analysis/ view/rehabilitation-and-reintegration-of-returning-foreign-terrorist-fighters (most recently accessed on 28.12.2016).

63 J. Horgan, K. Braddock (see Note 10), pp. 278-279.

64 The Constitution of the Republic of Estonia (Eesti Vabariigi põhiseadus). - RT I 1992, 26, 349 (in Estonian).

65 Available at http://www.vangla.ee/en/serving-sentence/social-work (most recently accessed on 10.10.2016). 
the individual (done by security forces), helping him with job placement, strengthening the families, giving monetary support (to the family also), and maintaining close relations with the person's case workers and mentors. ${ }^{* 66}$ All of these measures are, of course, highly resource-intensive.

In Estonia, the annual cost of maintaining the entire prison system and prisons in general is about 50 million euros. ${ }^{* 67}$ At the same time, the costs related to just one of the world's various de-radicalisation programmes alone can be in the millions of dollars per year. ${ }^{*} 68$ So even if there is a possibility of providing adequate teaching/training and the experts agree that the prisoner is highly reintegrated when leaving prison, Estonia might not have the financial resources to guarantee all the after-care measures the individual needs. And, again, the ultimate success of the reintegration programmes depends greatly on, besides the willingness of the society to take that person back into the fold, those after-care measures. This might be the greatest challenge for Estonia.

\section{Conclusions}

The main aim with this article was to seek answers to the question of whether the prison system in Estonia, while incarcerating former ISIS terrorists, would be able also to fulfil the objectives it has set for execution of imprisonment, while taking into account (legal) cultural aspects of the different societies involved. Another important consideration is how to ensure integration of a former ISIS terrorist and, to a lesser extent, guarantee effectiveness of the de-radicalisation programme after a former terrorist has left the prison. Therefore, the cultural and de-radicalisation aspects were taken into account and investigated with the aid of the (legal) cultural model described.

In consequence, it can be said that in integration of a prisoner who holds a radical ideology rooted in Islam into Estonian society, an integration interface between two different cultures is involved. The terrorist is in a secular country and has to obey its rules established by men rather than by God, yet the terrorist's inner convictions are rooted in the radical Islamic tradition. This is something that has to be taken into account if the purpose of successful reintegration is to be achieved.

The article showed this and also explained the view that former terrorists' understanding of the idea of justice and their justifications for their acts are based on a misinterpretation of God and the Quran. That is, the terrorists were not properly indoctrinated and they do not understand the ideology and core values of the religion they believe they are representing. That is the reason most of these people have been extremely vulnerable to the extremist propaganda and 'teachings' of self-appointed imams. Finally, the most important aspect is that this is actually the essential reason a former terrorist can be re-educated and reintegrated.

All in all, we can conclude that prisons in Estonia might be able to provide adequate training and teaching of former terrorists, because of the presence of chaplains and experts working for the prisons. Regrettably, though, even if the prisoner is highly reintegrated and understands the true nature of Islam when leaving prison, the question remains of whether Estonia has the financial resources to ensure all the aftercare measures the former terrorist needs for living a law-abiding life outside prison. That might be one of the greatest challenges facing the Estonian prison system in light of globalisation, in the era of terrorism.

66 M. Dugas, A. W. Kruglanski. The quest for significance model of radicalization: Implications for the management of terrorist detainees. - Behavioral Sciences \& the Law 32 (2014) / 3, p. 434. - DOI: https://doi.org/10.1002/bsl.2122.

67 Available at http://www.aripaev.ee/uudised/2015/04/01/kolme-aastaga-5-mln-eurot-rohkem-pattide-huvanguks (most recently accessed on 2.1.2017) (in Estonian).

68 An example is provided in materials available via https://www.ipinst.org/2010/07/a-new-approach-deradicalization-programs-and-counterterrorism (most recently accessed on 12.1.2017). 